Selective synthesis of galactooligosaccharides containing $\beta(1 \rightarrow 3)$ linkages with Beta-galactosidase from Bifidobacterium bifidum

Vera Füreder, Barbara Rodriguez-Colinas, Fadia V. Cervantes, Lucia Fernandez-Arrojo, Ana Poveda, Jesus Jimenez-Barbero, Antonio 0. Ballesteros, Francisco J. Plou

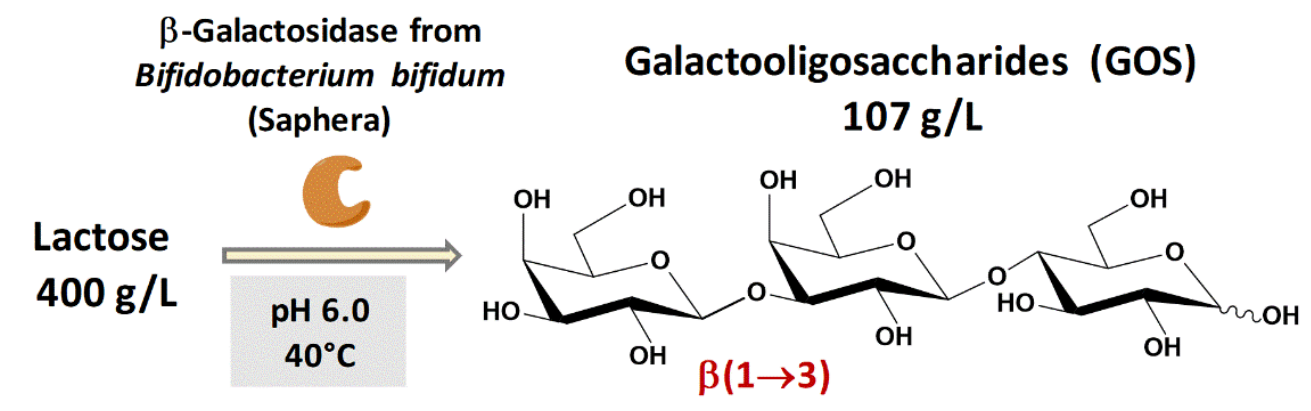

Published in:

Journal of Agricultural and Food Chemistry 68(17), 4930-4938 (2020) (DOI: https://doi.org/10.1021/acs.jafc.0c00997 


\section{Selective synthesis of galactooligosaccharides containing} $\beta(1 \rightarrow 3)$ linkages with Beta-galactosidase from Bifidobacterium bifidum (Saphera)

Vera Füredera, Barbara Rodriguez-Colinas ${ }^{\mathrm{a}, \mathrm{b}}$, Fadia V. Cervantes ${ }^{\mathrm{a}}$, Lucia FernandezArrojo $^{a}$, Ana Povedac, Jesus Jimenez-Barbero ${ }^{c, d}$, Antonio O. Ballesteros ${ }^{a}$, Francisco J. Plou ${ }^{a}, *$

a Instituto de Catálisis y Petroleoquímica, CSIC, 28049 Madrid, Spain

b Departamento de Biotecnología, Facultad de Ciencias Experimentales, Universidad Francisco de Vitoria, 28223 Pozuelo de Alarcón, Madrid, Spain

' CIC bioGUNE, Basque Research and Technology Alliance (BRTA), 48160 Derio, Spain

d Ikerbasque, Basque Foundation for Science, Maria Diaz de Haro 3, 48013 Bilbao, Spain

* Corresponding author (Tel: +34-915854869; Fax: +34-915854760; E-mail: fplou@icp.csic.es). 


\section{ABSTRACT}

The transglycosylation activity of a novel commercial $\beta$-galactosidase from Bifidobacterium bifidum (Saphera) was evaluated. The optimal conditions of operation of this enzyme, measured with $o$-nitrophenyl- $\beta$-D-galactopyranoside, were $40^{\circ} \mathrm{C}$ and $\mathrm{pH}$ around 6.0. Although at low lactose concentrations the character of this enzyme was basically hydrolytic, an increase of lactose concentration to $400 \mathrm{~g} / \mathrm{L}$ resulted in a significant formation (107.2 g/L, 27\% yield) of prebiotic galactooligosaccharides (GOS). The maximum amount of GOS was obtained at a lactose conversion of approximately $90 \%$, which contrasts with other $\beta$-galactosidases, for which the highest GOS yield is achieved at 40-50\% lactose conversion. Using HPAEC-PAD, semipreparative HPLC-HILIC, MS, 1D and 2D NMR, we determined the structure of most of the GOS synthesized by this enzyme. The main identified products were Gal- $\beta(1 \rightarrow 3)$-Gal- $\beta(1 \rightarrow 4)$-Glc (3'-O-Beta-galactosyllactose), Gal- $\beta(1 \rightarrow 6)$-Glc (allolactose), Gal- $\beta(1 \rightarrow 3)$-Glc (3-galactosyl-glucose), Gal$\beta(1 \rightarrow 3)$-Gal (3-galactobiose) and the tetrasaccharide Gal- $\beta(1 \rightarrow 3)$-Gal- $\beta(1 \rightarrow 3)$-Gal$\beta(1 \rightarrow 4)$-Glc. In general, the $B$. bifidum $\beta$-galactosidase showed a tendency to form $\beta(1 \rightarrow 3)$ linkages followed by $\beta(1 \rightarrow 6)$, and more scarcely $\beta(1 \rightarrow 4)$.

Keywords: Galactooligosaccharides, Prebiotics, Transglycosylation, $\beta$ Galactosidase, Bifidobacteria, Glycosidases. 


\section{INTRODUCTION}

Beta-Galactosidases (Beta-D-galactoside galactohydrolases, EC 3.2.1.23) catalyze the hydrolysis of different oligosaccharides with a galactosyl moiety located at the nonreducing end.1,2 The dairy industry is taking advantage of this reaction to remove lactose from milk to obtain lactose-free products. ${ }^{3,4}$ Due to the high amount of people suffering from lactose intolerance, the demand for lactose-free products is steadily increasing. ${ }^{5}$ Apart from its hydrolytic activity, Beta-galactosidases are also able to catalyze transgalactosylation reactions in which lactose -or other carbohydrates- act as acceptor molecules of galactosyl units yielding di-, tri, tetra- or even higher oligomers called galactooligosaccharides (GOS). ${ }^{6-9}$ GOS chemically resemble the oligosaccharides present in human milk (HMOS) -which are structurally more complex-, and both families exhibit prebiotic properties. ${ }^{10-12}$ More precisely, they improve the gastrointestinal microbiota by promoting the growth and/or the activity of bifidobacteria and lactobacilli, ${ }^{13}$ which are regarded to have a beneficial effect on human health. ${ }^{14,15}$ In addition to their prebiotic activity, several studies describe that GOS are non-cariogenic, diminish the serum cholesterol level, prevent colon cancer, enhance the digestibility of milk and improve the lactose tolerance. ${ }^{16,17}$ Therefore, Beta-galactosidases from generally recognized as safe (GRAS) microorganisms have attracted the attention of the dairy industries for enriching their products with GOS and developing novel functional foods. ${ }^{13,18}$ According to their sequences and structures, most Beta-galactosidases belong to families GH1, GH2, GH35, GH42 and GH59 of glycosyl hydrolases. ${ }^{1,9}$

The yield and the composition of the synthesized GOS are influenced by the source of the enzyme and several reaction parameters including lactose concentration, $\mathrm{pH}$, temperature, and water activity. ${ }^{19-21}$ The percentage of GOS in the mixtures may vary in a wide range between $15-55 \%(w / w)$ depending on such conditions. ${ }^{22-25}$ The health promoting properties of GOS depend on their chemical composition, structure and degree of polymerization, which are highly influenced by the origin of the $\beta$-galactosidase. ${ }^{10}$ The chemical structure of the synthesized oligosaccharides (number of hexose units, types of linkages between them and carbohydrate composition) may affect their fermentation pattern by probiotic bacteria in the human intestine. ${ }^{26,27}$ Apparently, GOS mixtures 
synthesized by Beta-galactosidases from probiotic microorganisms are consumed faster by probiotic species than those produced by other Beta-galactosidases. ${ }^{28-30}$ Bifidobacterium species are one of the most common organisms in the human gastrointestinal tract. ${ }^{30,31}$ It has been demonstrated that GOS produced by Betagalactosidases from Bifidobacterium species have a different structure and significantly higher prebiotic potential compared with commercial mixtures of GOS, ${ }^{28,32}$ probably due to the prevalence of $\beta(1 \rightarrow 3)$ and $\beta(1 \rightarrow 6)$ linkages, ${ }^{25}$ whilst $\beta(1 \rightarrow 4)$ and $\beta(1 \rightarrow 6)$ bonds prevail in commercial GOS.6,33 $\beta$-galactosidases from Bifidobacterium species typically belong to families $\mathrm{GH} 2$ and GH42.1,25 Interestingly, GOS synthesis catalyzed by $\beta$ galactosidases from bifidobacteria is not inhibited by the presence of glucose or galactose, ${ }^{34,35}$ which are commonly recognized as inhibitors of other Beta-galactosidases. ${ }^{36}$ A novel commercial $\beta$-galactosidase from Bifidobacterium bifidum (Saphera ${ }^{\circledR}$ ) was recently released to the market for obtaining lactose-free products. At moderate lactose concentrations (as those typically found in milk, whey permeate, kephir, etc.), this enzyme is described to synthesize a low amount of GOS compared with other $\beta$-galactosidases. In the present work, we have demonstrated that this property can be modulated by controlling lactose concentration. A detailed chemical characterization of the synthesized GOS was also performed. Saphera is an easily available preparation, which could facilitate its broad use for GOS synthesis at high scale. 


\section{MATERIALS AND METHODS}

\section{Materials}

The commercial $\beta$-galactosidase Saphera ${ }^{\circledR}$ (Novozym 46091) from Bifidobacterium bifidum was kindly supplied by Novozymes A/S (Bagsværd, Denmark). Lactose and $o$ nitrophenyl-Beta-D-galactopyranoside (ONPG) were from Sigma-Aldrich. The standards 3-O-Beta-galactosyl-galactose (3-galactobiose), 4-O-Beta-galactosyl-galactose (4galactobiose), 6-O-Beta-galactosyl-galactose (6-galactobiose), 6-O-Beta-galactosylglucose (allolactose) and 4'-O-Beta-galactosyl-lactose were from Carbosynth (Berkshire, UK). The rest of standards were synthesized following previous works developed in our laboratory. ${ }^{22,37,38}$ All other reagents and solvents were of the highest available purity and used as purchased.

\section{Determination of $\beta$-galactosidase activity}

The assay of $\beta$-galactosidase activity was performed using $o$-nitrophenyl-Beta-Dgalactopyranoside (ONPG) as substrate. The activity was measured at $40{ }^{\circ} \mathrm{C}$ following $o$ nitrophenol (ONP) release at $405 \mathrm{~nm}$ using a microplate reader (Versamax, Molecular Devices). The reaction was started by adding 10 oL of the enzyme solution (properly diluted) to 190 ?L of $15 \mathrm{mM}$ ONPG in $0.1 \mathrm{M}$ phosphate buffer (pH 6.8). The increase of absorbance at $405 \mathrm{~nm}$ was followed continuously at $40{ }^{\circ} \mathrm{C}$ during $5 \mathrm{~min}$. The molar extinction coefficient of $o$-nitrophenol at $\mathrm{pH} 6.8$ was $1627 \mathrm{M}^{-1} \mathrm{~cm}^{-1}$. One unit of activity $(U)$ was defined as that corresponding to the hydrolysis of $1 \mu \mathrm{mol}$ of ONPG per min under the above specified conditions.

\section{Optimum temperature and $\mathrm{pH}$}

The optimum temperature for the $\beta$-galactosidase activity was determined by mixing 50 $\mu \mathrm{L}$ of a properly diluted enzyme solution with $450 \mu \mathrm{L}$ of $15 \mathrm{mM}$ ONPG in $0.1 \mathrm{M}$ phosphate buffer ( $\mathrm{pH}$ 6.8). The mixture was incubated for $10 \mathrm{~min}$ at different temperatures between $10{ }^{\circ} \mathrm{C}$ and $70 \stackrel{\circ}{\circ} \mathrm{C}$. The reaction was stopped by adding $500 \mu \mathrm{L}$ of $0.4 \mathrm{M} \mathrm{Na}_{2} \mathrm{CO}_{3}$ and the absorbance at $405 \mathrm{~nm}$ was measured in endpoint mode using a microplate reader (Versamax, Molecular Devices). The optimum $\mathrm{pH}$ for the $\beta$-galactosidase activity was measured at $40{ }^{\circ} \mathrm{C}$ by performing the enzyme assay at different $\mathrm{pH}$ values (between 2.0 
and 9.0), under the conditions described above, measuring the slope of $o$-nitrophenol release with time. The molar extinction coefficient of $o$-nitrophenol for each $\mathrm{pH}$ was determined ( $\mathrm{pH} 2.0,378.65 \mathrm{M}^{-1} \mathrm{~cm}^{-1}$; $\mathrm{pH} 3.0,383.85 \mathrm{M}^{-1} \mathrm{~cm}^{-1}$; $\mathrm{pH} 4.0,441.98 \mathrm{M}^{-1} \mathrm{~cm}^{-1}$; pH 5.0, 495.38 $\mathrm{M}^{-1} \mathrm{~cm}^{-1}$; pH 6.0, 661.65 $\mathrm{M}^{-1} \mathrm{~cm}^{-1}$; pH 7.0, 2043.5 $\mathrm{M}^{-1} \mathrm{~cm}^{-1}$; pH 8.0, 4397.83 $\mathrm{M}^{-1} \mathrm{~cm}^{-1}$; pH 9.0, $4403 \mathrm{M}^{-1} \mathrm{~cm}^{-1}$ ). To minimize the buffer effect, solutions of $15 \mathrm{mM}$ ONPG were prepared using $0.1 \mathrm{M}$ Britton \& Robinson buffer, ${ }^{39}$ adjusted to the required pH. All the experiments were performed in triplicate and the error was expressed as the standard deviation of the three measurements.

\section{pH and thermal stability of $\beta$-galactosidase}

In order to evaluate the thermostability of the $\beta$-galactosidase, the enzyme was incubated in $0.1 \mathrm{M}$ phosphate buffer $\mathrm{pH} 6.8$ for 1 hour at different temperatures ranging from $4{ }^{\circ} \mathrm{C}$ to $70{ }^{\circ} \mathrm{C}$. The remaining activity towards ONPG was determined by performing enzymatic activity measurements as described above. The evaluation of the stability towards $\mathrm{pH}$ was performed incubating enzyme samples at $40{ }^{\circ} \mathrm{C}$ for 3 hours at various $\mathrm{pH}$ values (between pH 2.0 and $\mathrm{pH}$ 12.0) using the Britton \& Robinson buffer. The remaining activity was measured as described above.

\section{Production of galactooligosaccharides from lactose}

Lactose $(400 \mathrm{~g} / \mathrm{L} 34.7 \% \mathrm{w} / \mathrm{w}$ ) was dissolved in $20 \mathrm{~mL}$ of $0.1 \mathrm{M}$ phosphate buffer (pH 6.0). The biocatalyst was then added to adjust the Beta-galactosidase activity in the reaction mixture to $1.5 \mathrm{U} / \mathrm{mL}$ (ONPG units). The mixture was incubated at $40^{\circ} \mathrm{C}$ in an orbital shaker (Vortemp 1550) at $200 \mathrm{rpm}$. At different times, $750 \mu \mathrm{L}$ aliquots were harvested from the reaction vessel. The enzyme was inactivated by incubating the samples in a Thermomixer (Eppendorf) for $10 \mathrm{~min}$ at $96^{\circ} \mathrm{C}$. Samples were then filtered using micro-centrifuge filter tubes, with 0.45 ? $\mathrm{m}$ cellulose acetate filters (National Scientific) at $4000 \mathrm{xg}$ for $5 \mathrm{~min}$. The samples were diluted with water (1:400 and 1:4000) and then analyzed using HPAECPAD.

\section{HPAEC-PAD analysis}

Products were analyzed by high-performance anion-exchange chromatography with pulsed amperometric detection (HPAEC-PAD) on a ICS3000 Dionex system (Dionex Corp., CA) consisting of a SP gradient pump, an autosampler (model AS-HV) and an electrochemical detector with a gold working electrode and $\mathrm{Ag} / \mathrm{AgCl}$ as reference 
electrode. All eluents were degassed by flushing with helium. A pellicular anion-exchange 4 x 250 mm Carbo-Pack PA-1 column (Dionex) connected to a 4 x 50 mm CarboPac PA-1 guard column was used at $30^{\circ} \mathrm{C}$. Eluents were prepared with Milli-Q water and $50 \% \mathrm{w} / \mathrm{v}$ ) $\mathrm{NaOH}$ (Sigma-Aldrich). The initial mobile phase was $15 \mathrm{mM} \mathrm{NaOH}$ at $1.0 \mathrm{~mL} / \mathrm{min}$ for 12 min. A mobile phase gradient from 15 to $200 \mathrm{mM} \mathrm{NaOH}$ was performed in $15 \mathrm{~min}$ at 1.0 $\mathrm{mL} / \mathrm{min}$, and it was maintained for $25 \mathrm{~min}$. The peaks were analyzed by using Chromeleon software. The identification of the different carbohydrates was performed on the basis of commercially available standards or products purified in the laboratory. For those compounds whose standards were not available at sufficient amount, quantification was done based on the calibration curve of standards with the same degree of polymerization.

\section{Purification of GOS}

For the purification of unidentified GOS, the reaction was carried out as described above and stopped after $22 \mathrm{~h}$ by heating the solution for $10 \mathrm{~min}$ at $96{ }^{\circ} \mathrm{C}$ to inactivate the biocatalyst. The reaction mixture was filtered using $0.45 \mu \mathrm{m}$ paper filters and purified by semipreparative hydrophilic interaction chromatography (HPLC-HILIC). A quaternary pump (Delta 600, Waters) coupled to a Lichrosorb- $\mathrm{NH}_{2}$ column (5 ?m, $10 \times 250 \mathrm{~mm}$, Merck) was used. The column temperature was kept at $25^{\circ} \mathrm{C}$. The acetonitrile/water $75 / 25(v / v)$ mobile phase was conditioned with helium and used as at a flow-rate of 6.25 $\mathrm{mL} / \mathrm{min}$ for $43 \mathrm{~min}$. Peaks were detected by using an evaporative light-scattering detector DDL-31 (Eurosep) equilibrated at $60^{\circ} \mathrm{C}$. A three-way flow splitter (model Accurate, Dionex) and a fraction collector II (Waters) were employed. The fractions containing the main peaks were collected and the solvent was removed by rotary evaporation.

\section{Mass spectrometry}

The MS analysis of purified galactooligosaccharides was assessed using a mass spectrometer with hybrid QTOF analyzer (model QSTAR, Pulsar i, AB Sciex). The sample was analyzed by direct infusion and ionized by electrospray (with methanol containing $1 \%$ of sodium iodide as ionizing phase) in positive reflector mode.

\section{Nuclear Magnetic Resonance (NMR)}

The structure of the oligosaccharides was determined by using a combination of $1 \mathrm{D}\left({ }^{1} \mathrm{H}\right.$, ${ }^{13} \mathrm{C}$ ) and 2D (COSY, NOESY, TOCSY, HSQC, HSQC-TOCSY, HMBC) NMR techniques. The samples were dissolved in $\mathrm{D}_{2} \mathrm{O}$, using TSP- $\mathrm{d}_{4}$ [3-(trimethylsilyl)propionic-2,2,3,3-d4 acid 
sodium salt] as chemical shift reference. Chemical shifts were expressed in parts per million with respect to the $0 \mathrm{ppm}$ point of TSP. The spectra were measured in a Bruker 800 AVIII spectrometer equipped with a 4-channels cryo TCI probe, with gradients in the $\mathrm{Z}$ axis, at a temperature of $298 \mathrm{~K}$. For the ${ }^{1} \mathrm{H}-{ }^{13} \mathrm{C}$ heteronuclear correlations (HSQC, HQSCTOCSY, HMBC), values of $5 \mathrm{ppm}$ and $1-2 \mathrm{~K}$ points, for the ${ }^{1} \mathrm{H}$ dimension, and $70 \mathrm{ppm}$ and 384 points for the ${ }^{13} \mathrm{C}$ dimension, were used. For the ${ }^{1} \mathrm{H}-1 \mathrm{H}$ homonuclear experiments (COSY, NOESY, ROESY), 5 ppm windows were used in both dimensions with a $1-2 \mathrm{~K}$ x 384 point matrix. For the NOESY experiments, mixing times of 500-600 ms were used. The spinlock time was set to $300 \mathrm{~ms}$ for ROESY and 60/100 ms for HSQC-TOCSY experiments. The standard pulse sequences used were provided by Bruker. 


\section{RESULTS AND DISCUSSION}

\section{Effect of pH and temperature on activity and stability of Bifidobacterium bifidum Beta-galactosidase}

The hydrolytic activity of commercial Bifidobacterium bifidum $\beta$-galactosidase (Saphera), measured with $o$-nitrophenyl-Beta-D-galactopyranoside (ONPG) as substrate, was $1506 \pm$ $0.1 \mathrm{U} / \mathrm{mL}$, determined at $40{ }^{\circ} \mathrm{C}$ and $\mathrm{pH} 6.8$, which are the optimal conditions reported for several Beta-galactosidases from Bifidobacteria. $34,35,40$

In order to determine the optimum conditions of operation of this novel enzymatic preparation, a series of activity assays were performed at a fixed $\mathrm{pH}$ value (6.8) and different temperatures. The optimum temperature of the Beta-galactosidase from $B$. bifidum (Saphera) was found to be $40{ }^{\circ} \mathrm{C}$ (Fig. 1a). Furthermore, the thermostability was analyzed measuring the residual activity the enzyme in $0.1 \mathrm{M}$ phosphate buffer (pH 6.8) after $1 \mathrm{~h}$ incubation. The $\beta$-galactosidase showed a rapid inactivation at temperatures above $50{ }^{\circ} \mathrm{C}$ (Fig. 1b). The thermal stability was significantly lower than that reported for other related enzymes, such as $\beta$-glycosidases from Sulfolobus solfataricus and Pyrococcus furiosus. ${ }^{41}$ However, the $\beta$-galactosidase from B. bifidum showed a higher thermostability compared to Beta-galactosidases from other Bifidobacterium species like B. breve. ${ }^{25}$

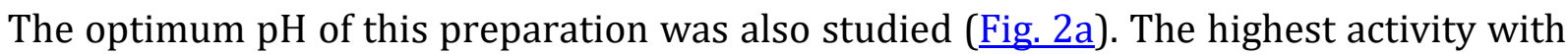
ONPG was obtained at in the range pH 5.7-6.4. Regarding the stability of the enzyme at different $\mathrm{pH}$ values, the results showed that the $\beta$-galactosidase displayed good stability in the $\mathrm{pH}$ range 5.0-10.0, after 3 hours of incubation at $40{ }^{\circ} \mathrm{C}$ ( $\underline{\text { Fig. } 2 \mathrm{~b}}$ ). At $\mathrm{pH} 3.0$ and 11.0 the inactivation of the enzyme was very fast. In this context, the Beta-galactosidase from Bifidobacterium breve was rapidly inactivated at $\mathrm{pH} 9.0 .{ }^{25}$ Our results fit well with those described by Tzortis et al. using whole cells of B. bifidum NCIMB 41171, for which the optimum $\mathrm{pH}$ and temperature were $6.8-7.0$ and $40{ }^{\circ} \mathrm{C}$, respectively. ${ }^{34}$ The related $\beta$ galactosidase from $B$. longum showed optimal $\mathrm{pH}$ and temperature of $5.8-6.8$ and $45^{\circ} \mathrm{C}$, respectively. ${ }^{35}$ 


\section{GOS specificity of B. bifidum Beta-galactosidase}

The ability of $B$. bifidum $\beta$-galactosidase to synthesize galactooligosaccharides (GOS) was assessed. First, we followed by HPAEC-PAD the hydrolysis of lactose at $160 \mathrm{~g} / \mathrm{L}$ under the optimal conditions ( $\mathrm{pH} 6.0,40^{\circ} \mathrm{C}$ ). As shown in Fig. 3a, the main reaction catalyzed by this enzyme under these conditions was the hydrolysis. However, the formation of several transgalactosylation products was observed.

We further increased the lactose concentration to $400 \mathrm{~g} / \mathrm{L}$ to promote transfer reaction. The HPAEC-PAD chromatogram ( $\underline{\text { Fig. } 3 \mathrm{~b}})$ showed at least 19 peaks of which numbers 1,2 and 5 corresponded to galactose, glucose and lactose, respectively. The main reaction products corresponded to peaks 10,15 and 19 . We were able to purify peaks 15 and 19 by semipreparative HILIC for their characterization. For peak 15, the major signal in the mass spectrum in positive mode ( $\underline{\text { Fig. } 4 \mathrm{~A}}$ ) was at $\mathrm{m} / z$ 527.16, corresponding to the $\mathrm{M}+[\mathrm{Na}]^{+}$ion of a trisaccharide. The 1D and 2D NMR spectra indicated that the structure of the compound fitted well with the trisaccharide 3'-0- $\beta$-galactosyl-lactose [Gal- $\beta(1 \rightarrow 3)$-Gal$\beta(1 \rightarrow 4)-G l c]$, which was previously identified and characterized in our laboratory studying the GOS synthesis with $\beta$-galactosidase from Aspergillus oryzae. ${ }^{22}$

The main signal in the mass spectrum of peak 19 (Fig. 4B) was at $m / z$ 689.21, corresponding to the $\mathrm{M}+[\mathrm{Na}]^{+}$ion of a tetrasaccharide. The ${ }^{1} \mathrm{H}-\mathrm{NMR}-$ based information for the major product of this peak was fairly similar to that recorded for peak 15, although it clearly displayed one additional anomeric proton (Figs. 5A and 5B). The analysis demonstrated that the Gal rings were not substituted at position 4, and only 3-Gal glycosylated moieties could be found. As for peak 15, the existing Glc ring was glycosylated position 4 . Therefore, the structure of the compound was determined to be 3 '-0- $\beta-(3-$ galactobiosyl)-lactose [Gal- $\beta(1 \rightarrow 3)-G a l-\beta(1 \rightarrow 3)-G a l-\beta(1 \rightarrow 4)-G l c]$ in a non-ambiguous manner. Fig. 5 shows the similarity of the ${ }^{1} \mathrm{H}$-NMR spectra of peaks 15 and 19 . Both positions $\alpha$ - and $\beta$ - at the reducing end were unambiguously identified for these compounds by the HSQC spectrum.

Peaks 8 and 9 were identified as the trisaccharide 6'-O-Beta-galactosyl-lactose and the disaccharide 3-O-Beta-galactosyl-glucose, respectively, using purified standards from $K$. lactis Beta-galactosidase reactions. ${ }^{42}$ With commercial standards it was also possible to identify peak 12 as the trisaccharide 4'-0-Beta-galactosyl-lactose and several 
disaccharides with different glycosidic bonds, involving two units of galactose (peak 3, 6galactobiose; peak 6, 3-galactobiose; peak 7, 4-galactobiose) or galactose-glucose (peak 4, Gal- $\beta(1 \rightarrow 6)$-Glc, allolactose; peak 9, Gal- $\beta(1 \rightarrow 3)-G l c)$.

One more reaction product (peak 13) was also partially purified by semipreparative HPLC. The mass spectrum showed that the main signal corresponded to a trisaccharide. Although the purity of this sample was not enough for a precise structure determination, the identity of the components of the mixture was further studied. From the NMR data, different glycosylation positions could be detected. For the Gal-Gal linkages, both Beta $(1 \rightarrow 3)$ and $\operatorname{Beta}(1 \rightarrow 4)$ disaccharide fragments were found, with similar proportions. For the Gal-Glc linkages, the Beta $(1 \rightarrow 4)$ position was predominant, but minor Beta $(1 \rightarrow 3)$ as well as minute fractions of Beta $(1 \rightarrow 2)$ linked moieties were also detected. Therefore, the mixture within peak 13 is composed of the Gal- $\beta(1 \rightarrow 3)$-Gal- $\beta(1 \rightarrow 4)$-Glc and Gal- $\beta(1 \rightarrow 4)$-Gal$\beta(1 \rightarrow 4)$-Glc trisaccharides as major products, together with the Gal- $\beta(1 \rightarrow 3)$-Gal- $\beta(1 \rightarrow 3)$ Glc, Gal- $\beta(1 \rightarrow 4)$-Gal- $\beta(1 \rightarrow 3)$-Glc analogues as minor components. Such assignations were performed on the basis of previous publications. ${ }^{43-46}$ Additionally, small amounts of products with the Glc moiety glycosylated at position 2 were present.

In a recent paper, using the $\beta$-galactosidase activity from several Pantoea anthophila strains, we were able to identify peak 14 as $3^{\prime}$-O-galactosyl-allolactose (Gal- $\beta(1 \rightarrow 3)$-Gal$\beta(1 \rightarrow 6)$-Glc). ${ }^{47}$ Regarding peak 10 , one of the most abundant in the GOS mixture, we believe that it could be composed by three galactosyl residues bound by $\beta(1 \rightarrow 3)$ linkages [Gal- $\beta(1 \rightarrow 3)$-Gal- $\beta(1 \rightarrow 3)$-Gal, 3-galactotriose]. This assumption is based on the enzyme specificity, the relative retention times and the presence of a significant amount of 3galactobiose, which could serve as galactosyl acceptor. However, we were not able to isolate it with enough purity for NMR analysis. Peaks 11, 16, 17 and 18 remained unidentified, but all of them were minor components of the mixture.

Our results fit well with those obtained using other B. bifidum strains. Depeint et al. ${ }^{48}$ and Goulas et al. ${ }^{49}$ reported the presence of $\beta(1 \rightarrow 3)$ linkages, with less participation of $\beta(1 \rightarrow 4)$ and $\beta(1 \rightarrow 6)$ bonds, in the GOS mixture obtained with $\beta$-galactosidase from $B$. bifidum NCIMB41171. However, Rabiu et al. identified, in addition to $\beta(1 \rightarrow 3)$ linkages, several $\beta(1 \rightarrow 6)$ and $\beta(1 \rightarrow 4)$ bonds. ${ }^{28}$ This partially agrees with our findings, but it is well studied 
that there are more than one $\beta$-galactosidase in Bifidobacteria strains, and the synthesized oligosaccharides may vary. 40,49

\section{Progress of GOS formation}

The progress of GOS formation was followed by HPAEC-PAD. Experimental conditions were $400 \mathrm{~g} / \mathrm{L}$ lactose in $0.1 \mathrm{M}$ sodium phosphate buffer (pH 6.0), $40{ }^{\circ} \mathrm{C}$ and $1.5 \mathrm{U} / \mathrm{mL}$ (ONPG units). Table 1 shows the concentrations of the main reaction products at different times. Under the above conditions, the point of maximum GOS production $(107.2 \mathrm{~g} / \mathrm{L}, 27 \%$ of total sugars in the mixture) was obtained at $50.5 \mathrm{~h}$. At this point, the rest of components in the mixture were glucose (38\%), galactose $(26 \%)$ and lactose (9\%). It is worth noting that the time required to get the maximum GOS yield depends inversely on the amount of enzyme; however, as occurs in this kind of kinetically-controlled reactions, ${ }^{50-52}$ the GOS concentration at this point is not affected by the amount of biocatalyst. Rabiu et al. reported GOS yields between 24.7-47.6\% employing 30\% (w/w) lactose and five different species of bifidobacteria, including B. bifidum BB-12 (37.6\% yield). ${ }^{28}$ Tzortzis et al. demonstrated that using whole-cells of $B$. bifidum NCIMB41171 the maximum GOS yield was $35 \%$ employing $55 \%(\mathrm{w} / \mathrm{w})$ lactose. ${ }^{34}$

At the point of maximum GOS concentration, the most abundant GOS corresponded to 3'galactosyl-lactose (17.7 g/L), allolactose (16.2 g/L), 3-0- $\beta$-galactosyl-glucose (9.0 g/L), and 3-galactobiose $(8.2 \mathrm{~g} / \mathrm{L})$, apart from unidentified peak 10 . These results confirm that the enzyme has a clear tendency to form $\beta(1 \rightarrow 3)$ linkages followed by $\beta(1 \rightarrow 6)$. However, only a small proportion of products containing new $\beta(1 \rightarrow 4)$ linkages were observed. It is worth noting that the GOS synthesis using B. bifidum Beta-galactosidase resulted in a high amount of disaccharides (approx. $40.4 \mathrm{~g} / \mathrm{L}$ ), with allolactose, 3-0-Beta-galactosyl-glucose and 3-galactobiose as the main components of this fraction. In this context, Böger et al. recently reported that most probiotic strains of gut bacteria exhibited a preference for DP2 galactooligosaccharides. ${ }^{53}$

Fig. 6 represents the profile of GOS concentration as a function of lactose conversion. It is remarkable, compared with other $\beta$-galactosidases, that the GOS concentration increased progressively until $80 \%$ of initial lactose has disappeared. Then, the yield of GOS was nearly invariable until approximately $93 \%$ of lactose was consumed. These results contrast with those obtained with Bacillus circulans $^{37}$ and Aspergillus oryzae ${ }^{22} \beta-$ 
galactosidases, for which the maximum concentration of GOS was achieved at approximately $40-50 \%$ of lactose conversion. Thereafter, GOS are hydrolyzed by the enzyme, in particular those containing $\beta(1 \rightarrow 4)$ linkages. The profile obtained with $B$. bifidum Beta-galactosidase resembles that of Kluyveromyces lactis lactase, as the maximum GOS yield was also achieved at approximately $95 \%$ of lactose conversion. ${ }^{42}$ In this context, Hsu et al., using a $\beta$-galactosidase from B. longum, reported a maximum GOS yield of 32.5\%, which obtained at approximately $60 \%$ lactose conversion, and was followed by a hydrolysis of the synthesized GOS. 35

In conclusion, the commercial preparation Saphera gave rise to a moderate GOS yield $(27 \%)$ compared with other Beta-galactosidases. However, the predominance of $\beta(1 \rightarrow 3)$ linkages in the synthesized GOS has several advantages with respect to other commercial GOS mixtures. First, the production of GOS with Saphera can be easily controlled because GOS hydrolysis only takes place when approximately 95\% of the initial lactose has disappeared. Second, it has been reported that GOS containing $\beta(1 \rightarrow 3)$ bonds are metabolized by probiotic bacteria faster than similar GOS containing other linkages, in particular $\beta(1 \rightarrow 4) .{ }^{29}$ There is a general consensus that GOS synthetized with $\beta$ galactosidases from probiotic strains exert a more marked effect on the growth of these probiotic strains. $28,34,48$

\section{ABBREVIATIONS}

GOS, galactooligosaccharides; HMOS, human milk oligosaccharides; ONPG, $o$-nitrophenyl$\beta$-D-galactopyranoside; GRAS, generally recognized as safe; HPAEC-PAD, highperformance anion-exchange chromatography with pulsed amperometric detection; HPLC, high-performance liquid chromatography; HILIC, hydrophilic interaction liquid chromatography; MS, mass spectrometry; QTOF, quadrupole time of flight; NMR, nuclear magnetic resonance; COSY, correlation spectroscopy; NOESY, nuclear overhauser effect spectroscopy ; TOCSY, total correlation spectroscopy; HSQC, heteronuclear single quantum correlation; HMBC, heteronuclear multiple bond correlation; TSP-d4, 3(trimethylsilyl)propionic-2,2,3,3-d4 acid sodium salt; DP, degree of polymerization. 


\section{ACKNOWLEDGEMENTS}

We thank Ramiro Martínez (Novozymes A/S, Madrid, Spain) for supplying Saphera ${ }^{\circledR}$ and for useful suggestions. Vera Füreder thanks the European Union for a grant of the Erasmus+ Program. We also thank CONACYT (Mexico) for a Ph.D. grant to Fadia V. Cervantes.

\section{FUNDING SOURCES}

This work was supported by a grant from the Spanish Ministry of Economy and Competitiveness (BIO2016-76601-C3-1). The group at CIC bioGUNE thanks Agencia Estatal de Investigación (Spain) for the Severo Ochoa Excellence Accreditation (SEV-20160644). 


\section{REFERENCES}

1. Plou, F. J.; Polaina, J.; Sanz-Aparicio, J.; Fernandez-Lobato, M., $\beta$-Galactosidases for lactose hydrolysis and galactooligosaccharide synthesis. In Microbial Enzyme Technology in Food Applications, Ray, R. C.; Rosell, C. M., Eds. CRC Press: 2016; pp 123-146.

2. Husain, Q., b-Galactosidases and their potential applications: A review. Crit. Rev. Biotechnol. 2010, 30, 41-62.

3. Adam, A. C.; Rubio-Texeira, M.; Polaina, J., Lactose: The milk sugar from a biotechnological perspective. Crit. Rev. Food Sci. Nutr. 2004, 44, 553-557.

4. Dekker, P. J. T.; Koenders, D.; Bruins, M. J., Lactose-free dairy products: Market developments, production, nutrition and health benefits. Nutrients 2019, 11 .

5. Zolnere, K.; Ciprovica, I. The comparison of commercially available ßGalactosidases for dairy industry: Review. Research for Rural Development 2017, 1, 215222.

6. Torres, D. P.; Goncalves, M.; Teixeira, J. A.; Rodrigues, L. R., GalactoOligosaccharides: Production, properties, applications, and significance as prebiotics. Compr. Rev. Food Sci. Food Saf. 2010, 9, 438-454.

7. Osman, A., Synthesis of Prebiotic Galacto-Oligosaccharides: Science and Technology. In Probiotics, Prebiotics, and Synbiotics: Bioactive Foods in Health Promotion, Watson, R.; Preedy, V., Eds. Academic Press: 2015; pp 135-154.

8. Ruiz-Matute, A. I.; Corzo-Martinez, M.; Montilla, A.; Olano, A.; Copovi, P.; Corzo, N., Presence of mono-, di- and galactooligosaccharides in commercial lactose-free UHT dairy products. J. Food Compos. Anal. 2012, 28, 164-169.

9. Marin-Navarro, J.; Talens-Perales, D.; Oude-Vrielink, A.; Cañada, F. J.; Polaina, J., Immobilization of thermostable b-galactosidase on epoxy support and its use for lactose hydrolysis and galactooligosaccharides biosynthesis. World J. Microbiol. Biotechnol. 2014, 30, 989-998.

10. Rodriguez-Colinas, B.; Kolida, S.; Baran, M.; Ballesteros, A. O.; Rastall, R. A.; Plou, F. J., Analysis of fermentation selectivity of purified galacto-oligosaccharides by in vitro human faecal fermentation. Appl. Microbiol. Biotechnol. 2013, 97, 5743-5752. 
11. Corzo, N.; Alonso, J. L.; Azpiroz, F.; Calvo, M. A.; Cirici, M.; Leis, R.; Lombo, F.; MateosAparicio, I.; Plou, F. J.; Ruas-Madiedo, P.; Ruperez, P.; Redondo-Cuenca, A.; Sanz, M. L.; Clemente, A., Prebiotics: Concept, properties and beneficial effects. Nutr.Hosp. 2015, 31, 99-118.

12. Shadid, R.; Haarman, M.; Knol, J.; Theis, W.; Beermann, C.; Rjosk-Dendorfer, D.; Schendel, D. J.; Koletzko, B. V.; Krauss-Etschmann, S., Effects of galactooligosaccharide and long-chain fructooligosaccharide supplementation during pregnancy on maternal and neonatal microbiota and immunity - a randomized, double-blind, placebo-controlled study. Am. J. Clin. Nutr. 2007, 86, 1426-1437.

13. Lamsal, B. P., Production, health aspects and potential food uses of dairy prebiotic galactooligosaccharides. J. Sci. Food Agric. 2012, 92, 2020-2028.

14. Rastall, R. A.; Gibson, G. R.; Gill, H. S.; Guarner, F.; Klaenhammer, T. R.; Pot, B.; Reid, G.; Rowland, I. R.; Sanders, M. E., Modulation of the microbial ecology of the human colon by probiotics, prebiotics and synbiotics to enhance human health: An overview of enabling science and potential applications. FEMS Microbiol. Ecol. 2005, 52, 145-152.

15. Neri-Numa, I. A.; Pastore, G. M., Novel insights into prebiotic properties on human health: A review. Food Res. Int. 2020, 131

16. Gosling, A.; Stevens, G. W.; Barber, A. R.; Kentish, S. E.; Gras, S. L., Recent advances refining galactooligosaccharide production from lactose. Food Chem. 2010, 121, 307-318. 17. Chen, Q.; Liu, M.; Zhang, P.; Fan, S.; Huang, J.; Yu, S.; Zhang, C.; Li, H., Fucoidan and galactooligosaccharides ameliorate high-fat diet-induced dyslipidemia in rats by modulating the gut microbiota and bile acid metabolism. Nutrition 2019, 65, 50-59.

18. Rodriguez-Colinas, B.; L., F.-A.; de Abreu, M.; Urrutia, P.; M., F.-L.; Ballesteros, A. O.; Plou, F. J., On the enzyme specificity for the synthesis of prebiotic galactooligosaccharides. In Advances in Enzyme Biotechnology, Shukla, P.; Pletschke; B., Eds. Springer: 2013; pp 2339.

19. Iqbal, S.; Nguyen, T. H.; Nguyen, T. T.; Maischberger, T.; Haltrich, D., ß-Galactosidase from Lactobacillus plantarum WCFS1: Biochemical characterization and formation of prebiotic galacto-oligosaccharides. Carbohydr. Res. 2010, 345, 1408-1416. 
20. Panesar, P. S.; Kaur, R.; Singh, R. S.; Kennedy, J. F., Biocatalytic strategies in the production of galacto-oligosaccharides and its global status. Int. J. Biol. Macromol. 2018, $111,667-679$.

21. Santibáñez, L.; Fernández-Arrojo, L.; Guerrero, C.; Plou, F. J.; Illanes, A., Removal of lactose in crude galacto-oligosaccharides by $\beta$-galactosidase from Kluyveromyces lactis. J. Mol. Catal. B: Enzym. 2016, 133, 85-91.

22. Urrutia, P.; Rodriguez-Colinas, B.; Fernandez-Arrojo, L.; Ballesteros, A. O.; Wilson, L.; Illanes, A.; Plou, F. J., Detailed analysis of galactooligosaccharides synthesis with bgalactosidase from Aspergillus oryzae. J. Agric. Food Chem. 2013, 61, 1081-1087.

23. Yin, H.; Bultema, J. B.; Dijkhuizen, L.; van Leeuwen, S. S., Reaction kinetics and galactooligosaccharide product profiles of the $\beta$-galactosidases from Bacillus circulans, Kluyveromyces lactis and Aspergillus oryzae. Food Chem. 2017, 225, 230-238.

24. Vera, C.; Córdova, A.; Aburto, C.; Guerrero, C.; Suárez, S.; Illanes, A., Synthesis and purification of galacto-oligosaccharides: state of the art. World J. Microbiol. Biotechnol. 2016,32 .

25. Arreola, S. L.; Intanon, M.; Suljic, J.; Kittl, R.; Pham, N. H.; Kosma, P.; Haltrich, D.; Nguyen, T. H., Two $\beta$-galactosidases from the human isolate Bifidobacterium breve DSM 20213: Molecular cloning and expression, biochemical characterization and synthesis of galacto-oligosaccharides. PLoS One 2014, 9.

26. Cardelle-Cobas, A.; Corzo, N.; Olano, A.; Pelaez, C.; Requena, T.; Avila, M., Galactooligosaccharides derived from lactose and lactulose: Influence of structure on Lactobacillus, Streptococcus and Bifidobacterium growth. Int. J. Food Microbiol. 2011, 149, 81-87.

27. Sanz, M. L.; Gibson, G. R.; Rastall, R. A., Influence of disaccharide structure on prebiotic selectivity in vitro. J. Agric. Food Chem. 2005, 53, 5192-5199.

28. Rabiu, B. A.; Jay, A. J.; Gibson, G. R.; Rastall, R. A., Synthesis and fermentation properties of novel galacto-oligosaccharides by beta-galactosidases from Bifidobacterium species. Appl. Environ. Microbiol. 2001, 67, 2526-2530.

29. Kittibunchakul, S.; Maischberger, T.; Domig, K. J.; Kneifel, W.; Nguyen, H. M.; Haltrich, D.; Nguyen, T. H., Fermentability of a novel galacto-oligosaccharide mixture by Lactobacillus spp. and Bifidobacterium spp. Molecules 2018, 23, 3352. 
30. Viborg, A. H., Diversity in $\beta$-galactosidase specificities within bifidobacterium: Towards an understanding of $\beta$-galactoside metabolism in the gut niche. Trends Glycosci. Glycotechnol. 2015, 27, J9-J12.

31. Zivkovic, A. M.; German, J. B.; Lebrilla, C. B.; Mills, D. A., Human milk glycobiome and its impact on the infant gastrointestinal microbiota. Proc. Natl. Acad. Sci.U.S.A. 2011, 108, 4653-4658.

32. Ferreira-Lazarte, A.; Gallego-Lobillo, P.; Moreno, F. J.; Villamiel, M.; HernandezHernandez, 0., In vitro digestibility of galactooligosaccharides: Effect of the structural features on their intestinal degradation. J. Agric. Food Chem. 2019, 67, 4662-4670.

33. Rodriguez-Colinas, B.; Fernandez-Arrojo, L.; Santos-Moriano, P.; Ballesteros, A. O.; Plou, F. J., Continuous packed bed reactor with immobilized $\beta$-galactosidase for production of galactooligosaccharides (GOS). Catalysts 2016, 6, 189.

34. Tzortzis, G.; Goulas, A. K.; Gibson, G. R., Synthesis of prebiotic galactooligosaccharides using whole cells of a novel strain, Bifidobacterium bifidum NCIMB 41171. Appl. Microbiol. Biotechnol. 2005, 68, 412-416.

35. Hsu, C. A.; Lee, S. L.; Chou, C. C., Enzymatic production of galactooligosaccharides by beta-galactosidase from Bifidobacterium longum BCRC 15708. J. Agric. Food Chem. $2007,55,2225-2230$.

36. Hatzinikolaou, D. G.; Katsifas, E.; Mamma, D.; Karagouni, A. D.; Christakopoulos, P.; Kekos, D., Modeling of the simultaneous hydrolysis-ultrafiltration of whey permeate by a thermostable $\beta$-galactosidase from Aspergillus niger. Biochem. Eng. J. 2005, 24, 161-172.

37. Rodriguez-Colinas, B.; Poveda, A.; Jimenez-Barbero, J.; Ballesteros, A. O.; Plou, F. J., Galacto-oligosaccharide synthesis from lactose solution or skim milk using the bgalactosidase from Bacillus circulans. J. Agric. Food Chem. 2012, 60, 6391-6398.

38. Rodriguez-Colinas, B.; De Abreu, M. A.; Fernandez-Arrojo, L.; De Beer, R.; Poveda, A.; Jimenez-Barbero, J.; Haltrich, D.; Ballesteros , A. O.; Fernandez-Lobato, M.; Plou, F. J., Production of galacto-oligosaccharides by the b-galactosidase from Kluyveromyces lactis: Comparative analysis of permeabilized cells versus soluble enzyme. J. Agric. Food Chem. $2011,59,10477-10484$.

39. Britton, H. T. S.; Robinson, R. A., Universal buffer solutions and the dissociation constant of veronal. J. Chem. Soc. 1931, 1456-1462. 
40. Goulas, A.; Tzortzis, G.; Gibson, G. R., Development of a process for the production and purification of alpha- and beta-galactooligosaccharides from Bifobacterium bifidum NCIMB 41171. Int. Dairy J. 2007, 17, 648-656.

41. Petzelbauer, I.; Splechtna, B.; Nidetzky, B., Development of an ultrahightemperature process for the enzymatic hydrolysis of lactose. III. Utilization of two thermostable beta-glycosidases in a continuous ultrafiltration membrane reactor and galacto-oligosaccharide formation under steady-state conditions. Biotechnol. Bioeng. $2002,77,394-404$.

42. Rodriguez-Colinas, B.; Fernandez-Arrojo, L.; Ballesteros, A.; Plou, F., Galactooligosaccharides formation during enzymatic hydrolysis of lactose: towards a prebiotic-enriched milk. Food Chem. 2014, 145, 388-394.

43. Yin, H.; Pijning, T.; Meng, X.; Dijkhuizen, L.; Van Leeuwen, S. S., Engineering of the Bacillus circulans $\beta$-galactosidase product specificity. Biochemistry 2017, 56, 704-711.

44. Van Leeuwen, S. S.; Kuipers, B. J. H.; Dijkhuizen, L.; Kamerling, J. P., Comparative structural characterization of 7 commercial galacto-oligosaccharide (GOS) products. Carbohydr. Res. 2016, 425, 48-58.

45. Van Leeuwen, S. S.; Kuipers, B. J. H.; Dijkhuizen, L.; Kamerling, J. P., 1 H NMR analysis of the lactose $/ \beta$-galactosidase-derived galacto-oligosaccharide components of Vivinal GOS up to DP5. Carbohydr. Res. 2014, 400, 59-73.

46. Van Leeuwen, S. S.; Kuipers, B. J. H.; Dijkhuizen, L.; Kamerling, J. P., Development of a 1H-NMR structural-reporter-group concept for the analysis of prebiotic galactooligosaccharides of the [ $\beta$-D-Galp- $(1 \rightarrow \mathrm{x})] \mathrm{n}-\mathrm{D}-\mathrm{Glcp}$ type. Carbohydr. Res. 2014, 400, 54-58. 47. Yañez-Ñeco, C. V.; Rodriguez-Colinas, B.; Amaya-Delgado, L.; Ballesteros, A. O.; Gschaedler, A.; Plou, F. J.; Arrizon, J., Galactooligosaccharide production from Pantoea anthophila strains isolated from "Tejuino", a Mexican traditional fermented beverage. Catalysts 2017, 7, 242.

48. Depeint, F.; Tzortzis, G.; Vulevic, J.; I'Anson, K.; Gibson, G. R., Prebiotic evaluation of a novel galactooligosaccharide mixture produced by the enzymatic activity of Bifidobacterium bifidum NCIMB 41171, in healthy humans: A randomized, double-blind, crossover, placebo-controlled intervention study. Am. J. Clin. Nutr. 2008, 87, 785-791. 
49. Goulas, T.; Goulas, A.; Tzortzis, G.; Gibson, G. R., Expression of four $\beta$-galactosidases from Bifidobacterium bifidum NCIMB41171 and their contribution on the hydrolysis and synthesis of galactooligosaccharides. Appl. Microbiol. Biotechnol. 2009, 84, 899-907.

50. Plou, F. J.; Gómez de Segura, A.; Ballesteros, A., Application of glycosidases and transglycosidases for the synthesis of oligosaccharides. In Industrial enzymes: Structure, Function and Application, Polaina, J.; MacCabe, A. P., Eds. Springer: New York, 2007; pp 141-157.

51. Buchholz, K.; Kasche, V.; Bornscheuer, U. T., Biocatalysts and Enzyme Technology. Wiley-VCH Verlag: Weinheim, 2005.

52. Torres, P.; Poveda, A.; Jimenez-Barbero, J.; Parra, J. L.; Comelles, F.; Ballesteros, A. O.; Plou, F. J., Enzymatic synthesis of $\alpha$-glucosides of resveratrol with surfactant activity. Adv. Synth. Catal. 2011, 353, 1077-1086.

53. Böger, M.; Van Leeuwen, S. S.; Lammerts Van Bueren, A.; Dijkhuizen, L., Structural identity of galactooligosaccharide molecules selectively utilized by single cultures of probiotic bacterial strains. J. Agric. Food Chem. 2019, 67, 13969-13977. 


\section{FIGURE CAPTIONS}

Figure 1: Effect of temperature on a) activity and b) stability of $\beta$-galactosidase from $B$. bifidum. For the activity assay, $0.1 \mathrm{M}$ phosphate buffer $(\mathrm{pH}$ 6.8) was used. For the thermostability assay, the enzyme was incubated in the same buffer at different temperatures for $1 \mathrm{~h}$. Residual activity was referred to the initial activity of the enzyme.

Figure 2: Effect of $\mathrm{pH}$ on a) activity and b) stability of $\beta$-galactosidase from B. bifidum. For the activity assay, $0.1 \mathrm{M}$ Britton \& Robinson buffer at different $\mathrm{pH}$ was used and the activity measured at $40{ }^{\circ} \mathrm{C}$. For the stability assay, the enzyme solution was incubated under different $\mathrm{pH}$ values at $40{ }^{\circ} \mathrm{C}$ for $3 \mathrm{~h}$. Residual activity was referred to the initial activity of the enzyme.

Figure 3: HPAEC-PAD analysis $(22 \mathrm{~h})$ of the reaction of lactose with B. bifidum $\beta$ galactosidase (Saphera) under optimal conditions ( $\mathrm{pH} 6.0,40{ }^{\circ} \mathrm{C}$ ) at two lactose concentrations: a) $160 \mathrm{~g} / \mathrm{L}$; b) $400 \mathrm{~g} / \mathrm{L}$. Peaks assignation: (1) Galactose; (2) Glucose; (3) 6-Galactobiose; (4) Allolactose; (5) Lactose; (6) 3-Galactobiose; (7) 4-Galactobiose; (8) 6'Galactosyl-lactose; (9) 3-0- $\beta$-Galactosyl-glucose; (12) 4'-Galactosyl-lactose; (13) Gal$\beta(1 \rightarrow 3)-G a l-\beta(1 \rightarrow 3)-G l c ;(14)$ 3'-Galactosyl-allolactose; (15) 3'-Galactosyl-lactose; (19) 3'-0- $\beta$-(3-Galactobiosyl)-lactose; $(10,11,16-18)$ unidentified.

Figure 4: ESI-TOF mass spectra (positive mode) of: A) Peak 15; B) Peak 19.

Figure 5: ${ }^{1} \mathrm{H}-\mathrm{NMR}$ spectra of the reaction products corresponding to peaks 13,15 and 19. The major product for peak 19 (A) corresponds to the tetrasaccharide Gal- $\beta(1 \rightarrow 3)$-Gal$\beta(1 \rightarrow 3)$-Gal- $\beta(1 \rightarrow 4)$-Glc $(\alpha / \beta)$. For peak 15 (B) the major product is Gal- $\beta(1 \rightarrow 3)$-Gal$\beta(1 \rightarrow 4)$-Glc $(\alpha / \beta)$. For peak $13(\mathrm{C})$ a mixture of trisaccharides (according to MS) containing all the possibilities for Gal- $\beta(1 \rightarrow 3 / 1 \rightarrow 4)$-Gal- $\beta(1 \rightarrow 4 / 1 \rightarrow 3 / 1 \rightarrow 2)-G l c(\alpha / \beta)$ is obtained. For the three peaks, small amounts of oligosaccharides with the reducing Glc residue glycosylated at position 2 have been found (signals at 5.4-5.5 ppm).

Figure 6: GOS formation vs. lactose conversion using $\beta$-galactosidase from B. bifidum (Saphera). Experimental conditions: $400 \mathrm{~g} / \mathrm{L}$ lactose in $0.1 \mathrm{M}$ sodium phosphate buffer $(\mathrm{pH}$ 6.0), $1.5 \mathrm{U} / \mathrm{ml}$ (ONPG units), $40 \stackrel{\circ}{\circ}$. 
Figure 1

Go back to Fig. 1
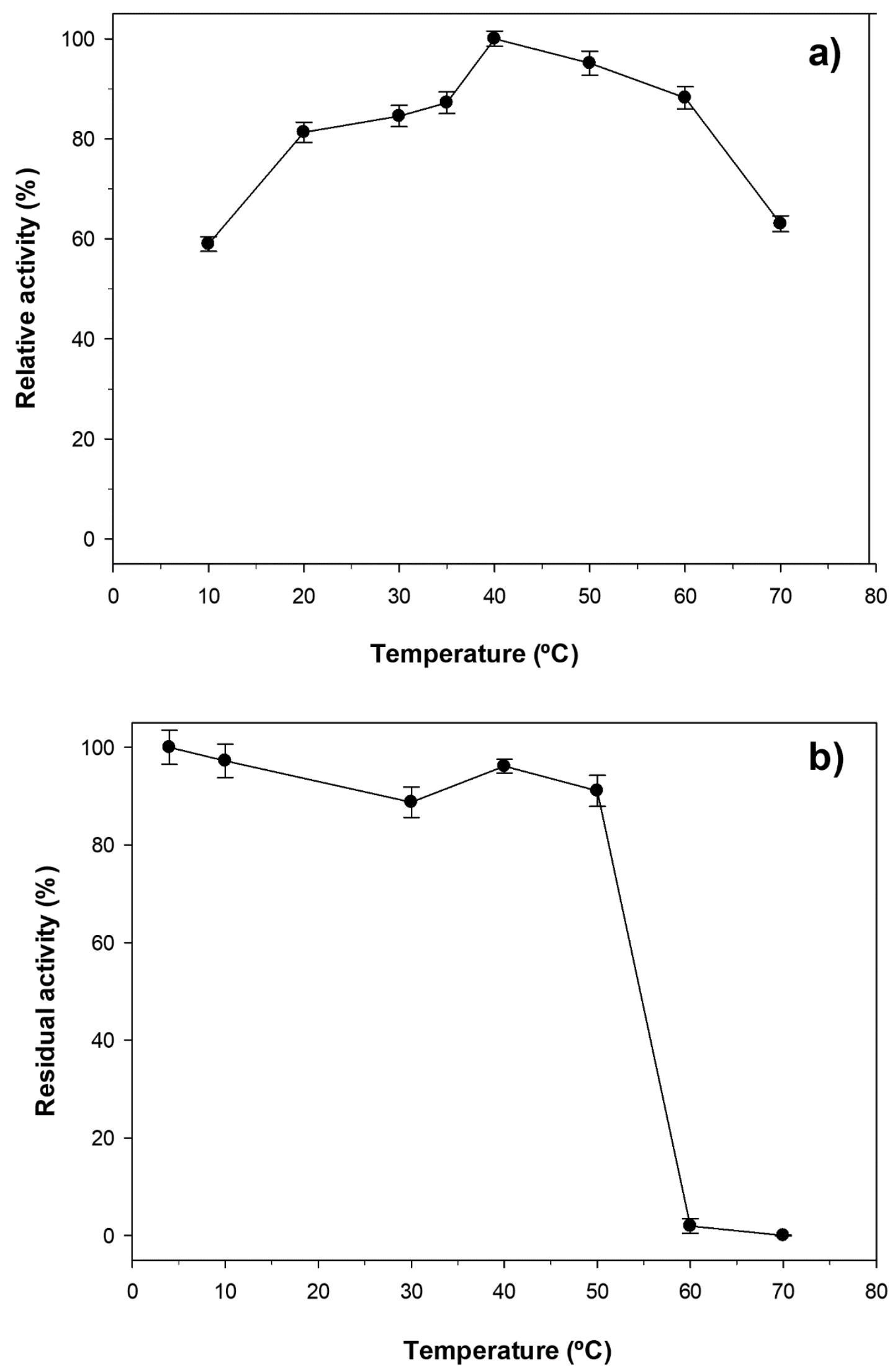
Figure 2

Go back to Fig. 2
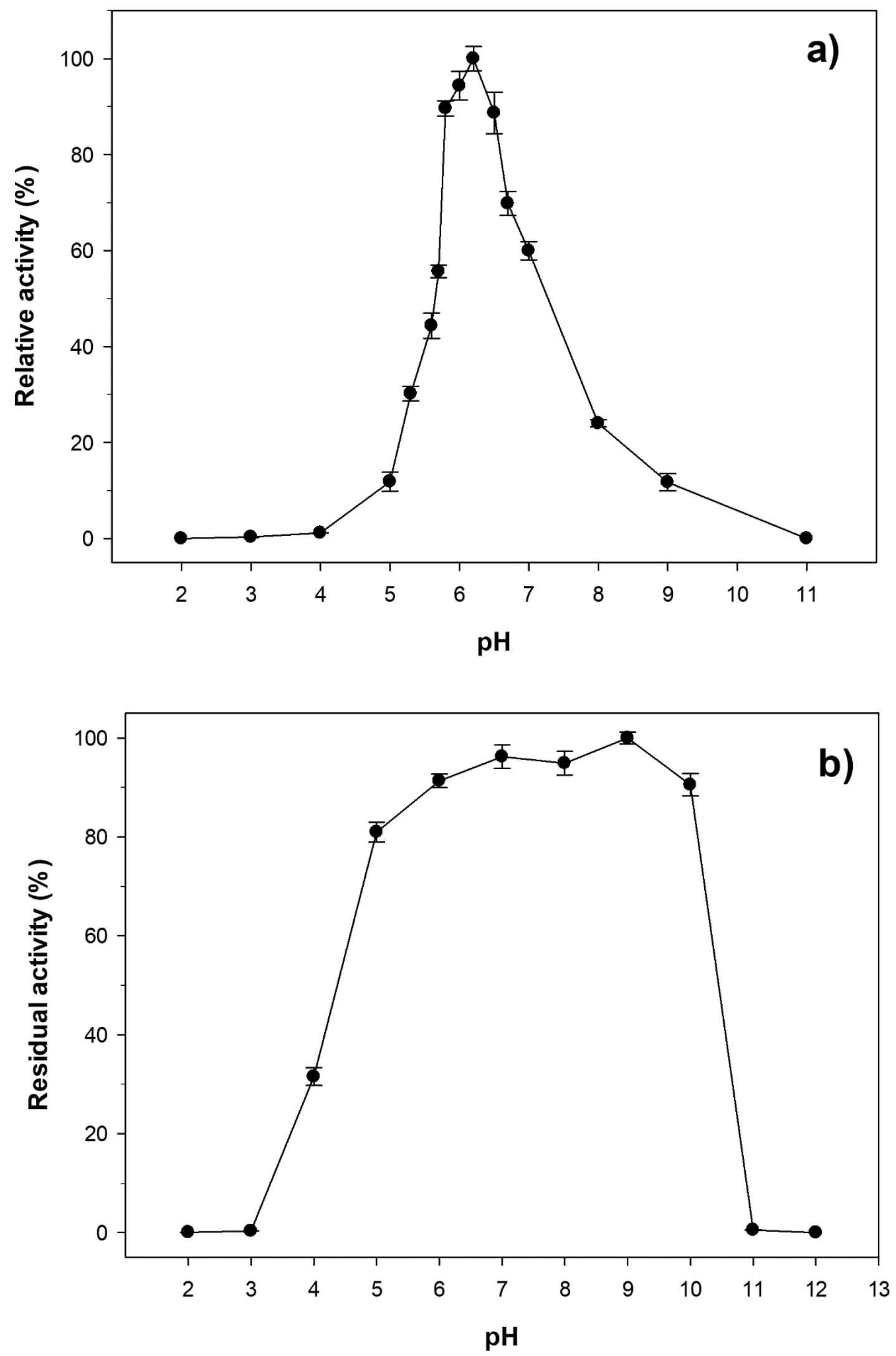
Figure 3

Go back to Fig. 3
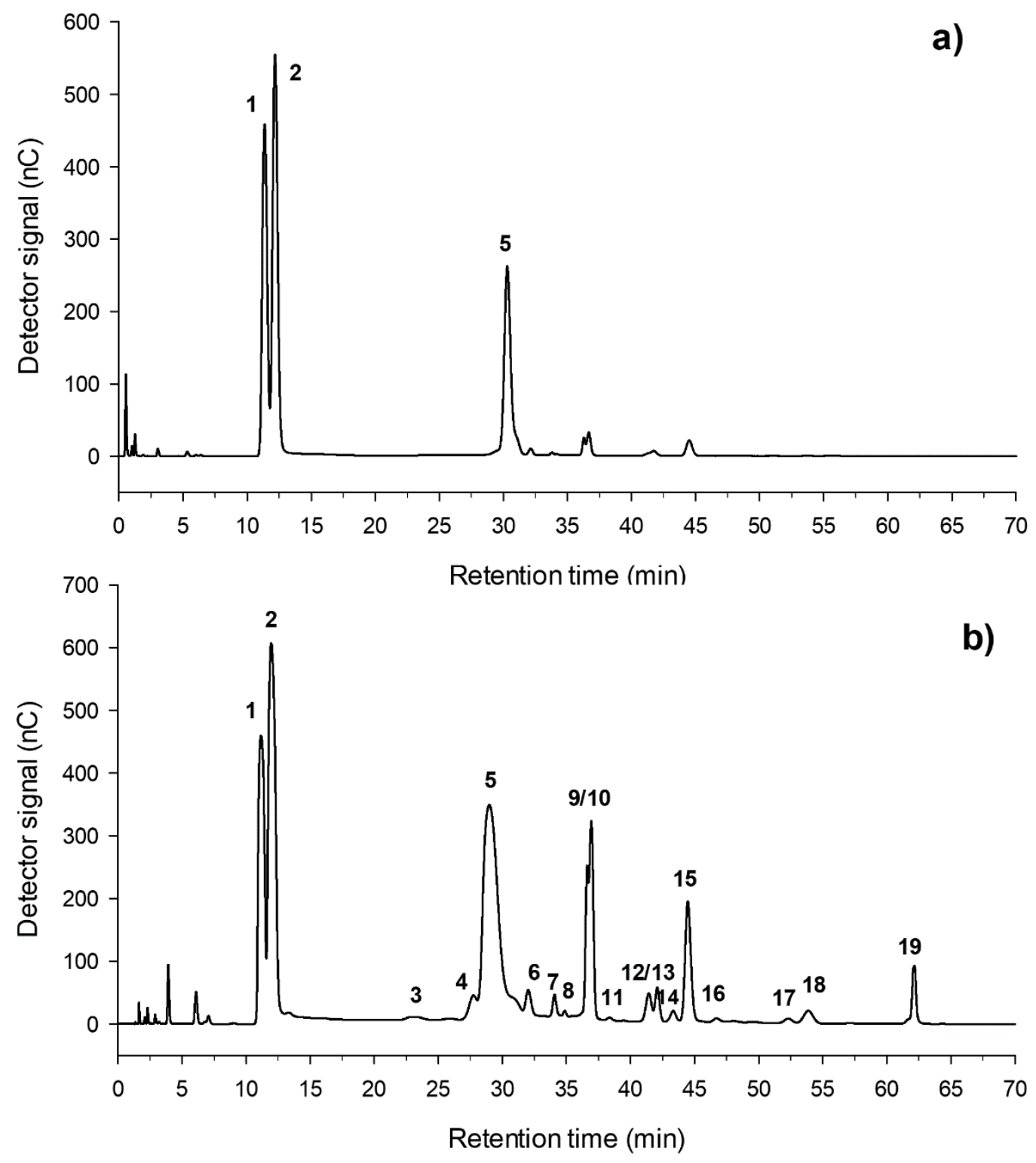
Figure 4

Go back to Fig. 4
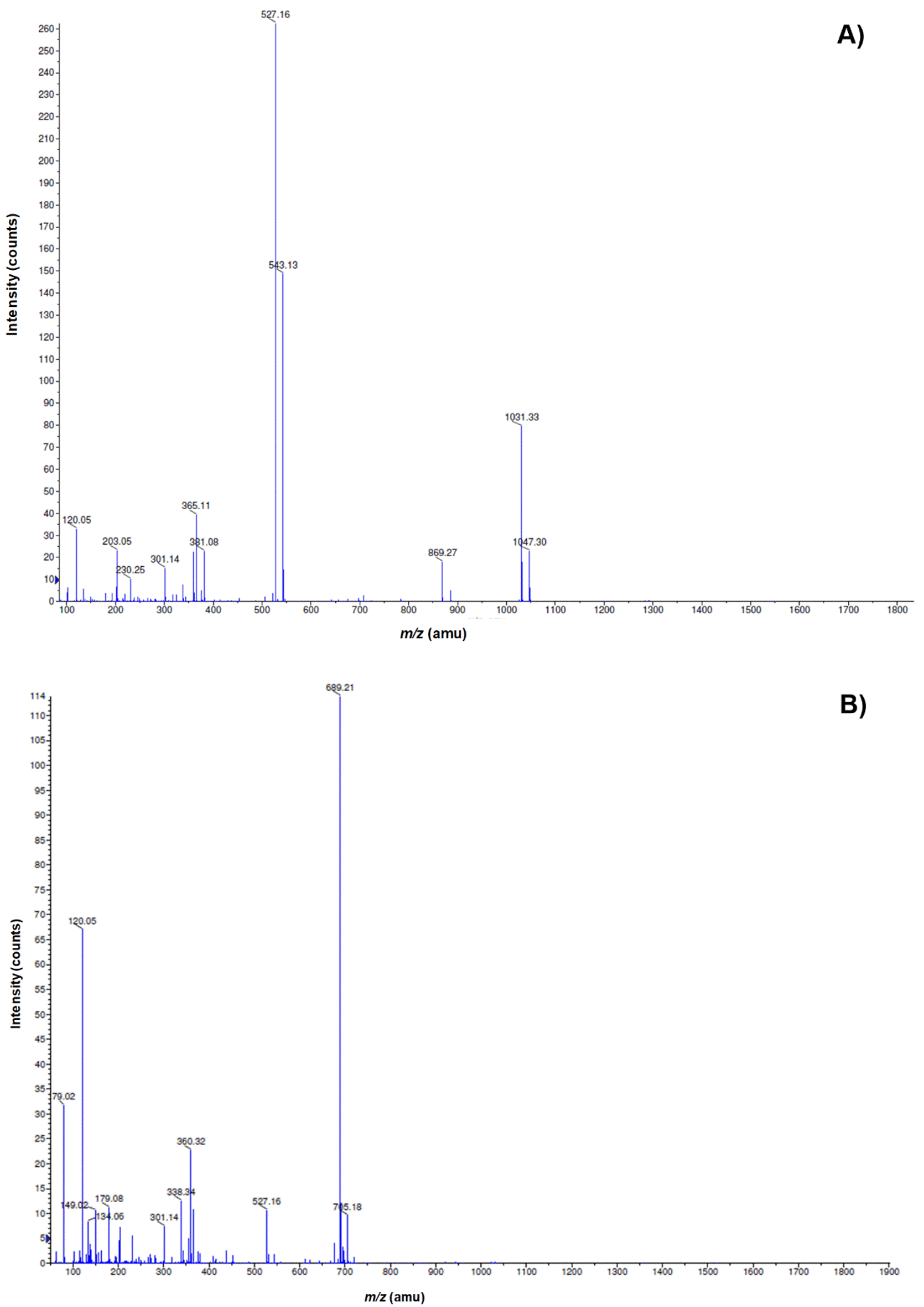
Figure 5

Go back to Fig. 5

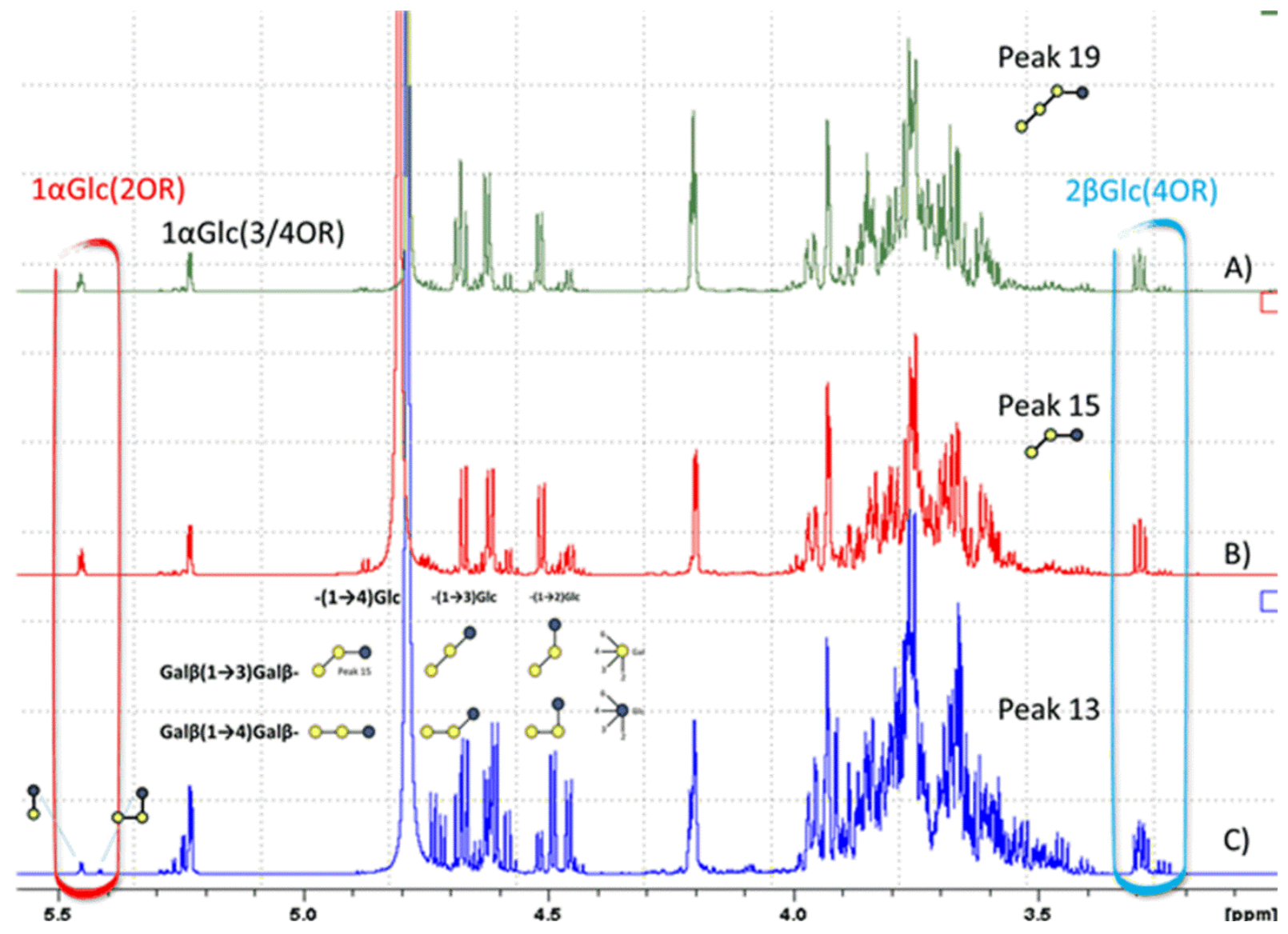


Figure 6

Go back to Fig. 6

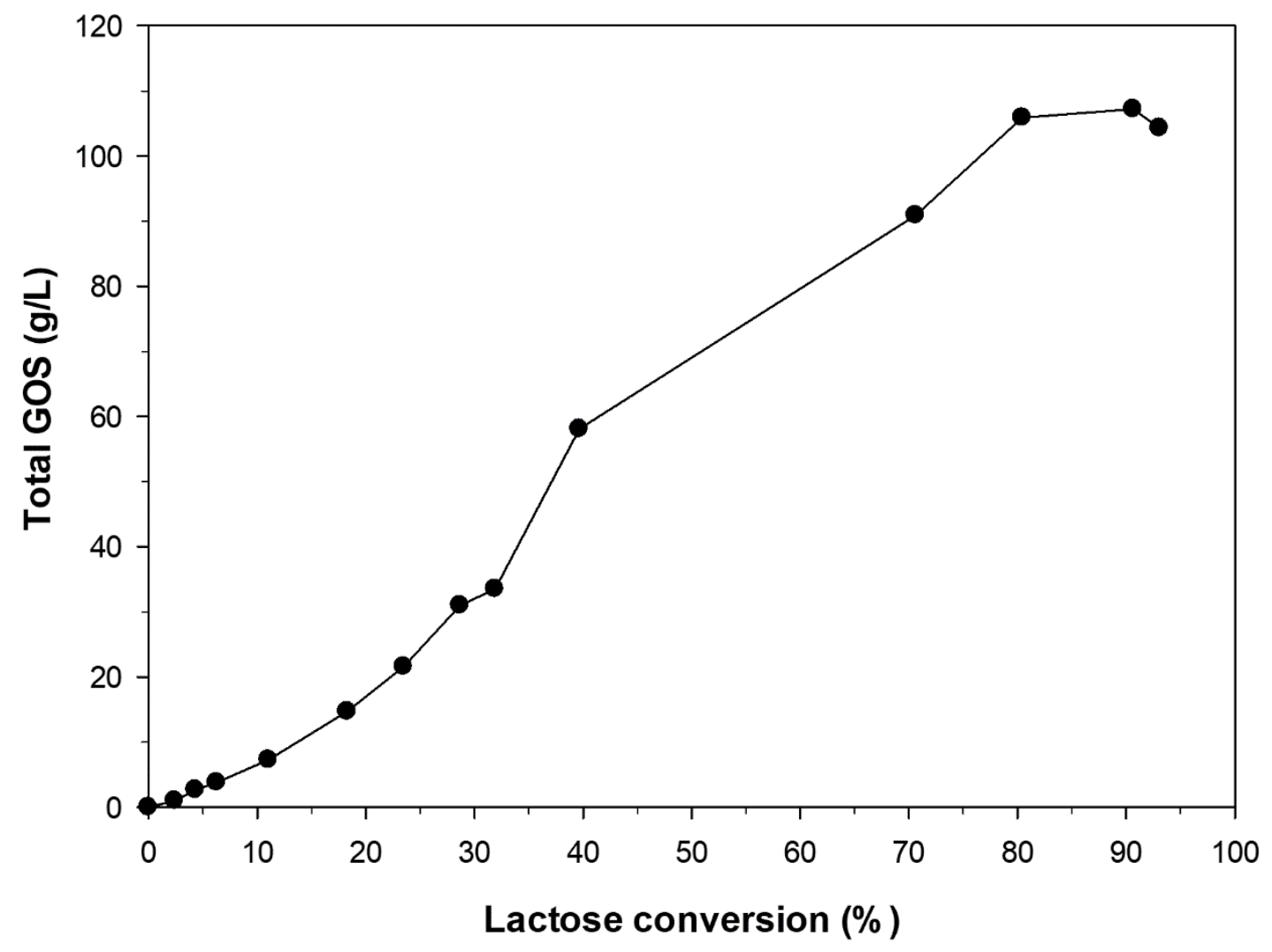


Table 1. Carbohydrate composition $(\mathrm{g} / \mathrm{L})$ of the reaction mixture using $\beta$ galactosidase from B. bifidum (Saphera). Experimental conditions: $400 \mathrm{~g} / \mathrm{L}$ lactose in $0.1 \mathrm{M}$ sodium phosphate buffer ( $\mathrm{pH} 6.0$ ), $1.5 \mathrm{U} / \mathrm{ml}, 40 \stackrel{\circ}{\circ} \mathrm{C}$.

\begin{tabular}{|c|c|c|c|c|c|c|c|c|c|c|c|c|c|}
\hline $\begin{array}{l}\text { Reaction } \\
\text { time } \\
\text { (min) }\end{array}$ & $\begin{array}{l}\text { Gal } \\
(\mathrm{g} / \mathrm{L})\end{array}$ & $\begin{array}{l}\text { Glc } \\
\text { (g/L) }\end{array}$ & $\begin{array}{l}\text { Lact } \\
(\mathrm{g} / \mathrm{L})\end{array}$ & $\begin{array}{l}\text { Gal- } \\
\text { 6-Gal } \\
\text { (g/L) }\end{array}$ & $\begin{array}{l}\text { Gal- } \\
\text { 6-Glc } \\
\text { (g/L) }\end{array}$ & $\begin{array}{l}\text { Gal- } \\
\text { 3-Gal } \\
\text { (g/L) }\end{array}$ & $\begin{array}{l}\text { Gal-4- } \\
\text { Gal } \\
(\mathrm{g} / \mathrm{L})\end{array}$ & $\begin{array}{l}\text { Gal- } \\
\text { 3-Glc } \\
\text { (g/L) }\end{array}$ & $\begin{array}{l}\text { Gal- } \\
4- \\
\text { Lact } \\
(\mathrm{g} / \mathrm{L})\end{array}$ & $\begin{array}{l}\text { Gal-3- } \\
\text { Lact } \\
\text { (g/L) }\end{array}$ & $\begin{array}{l}\text { Gal-3- } \\
\text { Gal-3- } \\
\text { Lact } \\
\text { (g/L) }\end{array}$ & $\begin{array}{l}\text { Other } \\
\text { GOS } \\
\text { (g/L) }\end{array}$ & $\begin{array}{l}\text { GOS } \\
\text { тот } \\
\text { (g/L) }\end{array}$ \\
\hline 0 & 0.0 & 0.0 & 400.0 & 0.0 & 0.0 & 0.0 & 0.0 & 0.0 & 0.0 & 0.0 & 0.0 & 0.0 & 0.0 \\
\hline 10 & 4.1 & 4.6 & 390.4 & 0.0 & 0.0 & 0.0 & 0.0 & 0.0 & 0.0 & 1.0 & 0.0 & 0.0 & 1.0 \\
\hline 20 & 6.6 & 8.0 & 382.7 & 0.0 & 0.0 & 0.0 & 0.0 & 0.1 & 0.6 & 1.6 & 0.1 & 0.3 & 2.7 \\
\hline 30 & 9.7 & 11.6 & 374.9 & 0.0 & 0.0 & 0.0 & 0.0 & 0.3 & 0.7 & 2.3 & 0.1 & 0.4 & 3.8 \\
\hline 60 & 16.1 & 20.8 & 355.8 & 0.0 & 0.0 & 0.0 & 0.0 & 0.8 & 1.3 & 3.8 & 0.3 & 1.2 & 7.3 \\
\hline 120 & 25.4 & 33.0 & 326.9 & 0.0 & 0.0 & 0.1 & 0.1 & 2.2 & 2.0 & 6.6 & 0.8 & 3.0 & 14.7 \\
\hline 180 & 30.6 & 41.7 & 306.1 & 0.0 & 0.0 & 0.0 & 0.2 & 3.8 & 2.5 & 8.7 & 1.2 & 5.2 & 21.6 \\
\hline 240 & 34.6 & 49.1 & 285.3 & 0.0 & 0.0 & 0.2 & 0.3 & 6.0 & 3.3 & 11.2 & 1.9 & 8.1 & 31.0 \\
\hline 300 & 38.8 & 55.3 & 272.4 & 0.0 & 0.0 & 0.2 & 0.4 & 6.5 & 3.2 & 11.8 & 2.2 & 9.2 & 33.5 \\
\hline 390 & 40.9 & 59.6 & 241.4 & 0.0 & 0.6 & 0.4 & 0.5 & 7.6 & 3.5 & 12.2 & 2.6 & 30.7 & 58.1 \\
\hline 1320 & 74.1 & 117.5 & 117.5 & 1.1 & 4.8 & 3.2 & 2.3 & 12.1 & 4.7 & 20.8 & 6.3 & 35.6 & 90.9 \\
\hline 1830 & 84.6 & 131.2 & 78.2 & 1.4 & 7.5 & 4.6 & 3.2 & 13.4 & 4.1 & 20.7 & 7.1 & 44.0 & 105.9 \\
\hline 3030 & 103.4 & 152.0 & 37.4 & 2.2 & 16.2 & 8.2 & 4.8 & 9.0 & 2.6 & 17.7 & 5.4 & 41.1 & 107.2 \\
\hline 4200 & 109.2 & 158.8 & 27.7 & 2.8 & 23.3 & 10.9 & 5.5 & 7.9 & 1.8 & 12.2 & 3.5 & 36.3 & 104.3 \\
\hline
\end{tabular}

Gal: Galactose; Glc: Glucose; Lact: Lactose; Gal-6-Gal: 6-galactobiose; Gal-6-Glc: Allolactose; Gal-3-Gal: 3galactobiose; Gal-4-Gal: 4-galactobiose; Gal-3-Glc: 3-galactosyl-glucose; Gal-4-Lact: 4'-galactosyl-lactose; Gal-3Lact: 3'-galactosyl-lactose; Gal-3-Gal-3-Lact: 3'-(3-galactobiosyl)-lactose; G0S

Go back to Table 1 